\title{
KITAB ISSENGNGI MAJEPPU: Naskah LTMM-IX
}

\section{The Manuscript of Issengngi Majeppu: Script LTMM-IX}

\author{
Idham \\ Balai Penelitian dan Pengembangan Agama Makassar \\ Jl. A.P. Pettarani No. 72 Makassar \\ Email: idbodi@yahoo.co.id
}

Naskah diterima tanggal 17 Februari 2015. Naskah direvisi tanggal 02 Maret 2015. Naskah disetujui tanggal 22 Mei 2015

\begin{abstract}
Abstrak
Issengi Majeppu adalah salah satu manuskrip (naskah kuno) yang ditemukan di Kecamatan Sendana Kabupaten Majene, Sulawesi Barat. Sebagai naskah kuno, ia tidak banyak tersebar di masyarakat awam, karena umumnya naskah kuno tersebut disakralkan oleh pemiliknya dan hanya dapat diakses oleh kalangan tertentu. Selain itu, sebagai naskah yang ditulis pada puluhan tahun yang silam, naskah kuno kurang bersahabat dengan dengan orang-orang belakangan, baik dari segi bahasa, aksara dan razam yang digunakan. Berdasarkan latar belakang tersebut, tulisan ini berusaha mengungkap isi kitab Issengi Majeppu (LTMM-IX) dengan menggunakan pendekatan filologi. Kajian terhadap naskah tersebut ditemukan bahwa, naskah ini ditulis dalam bahasa Bugis dengan aksara hurufu' serang (pegon) razam naskhi. Setiap tema bahasan diantarai basmalah dan pada bagian tersebut terdiri atas beberapa pasal. Untuk mengungkap isi, peneliti terlebih dahulu melakukan transliterasi dan penerjemahan. Kitab Issengi Majeppu merupakan kitab tasawuf yang di dalamnya membahas syariat, thariqat, hakikat, dan márifat, selain itu, kitab ini menyelipkan ilmu hubungan suami istri dan ilmu kekebalan.
\end{abstract}

Kata kunci: naskah klasik, manuskrip, issengi majeppu.

\begin{abstract}
Issengi Majeppu is one of the ancient manuscripts (codex) found in Sendana district, Majene regency, West Sulawesi Province. As ancient manuscript, it was not widely spread in public because most of them were sacred by its owner and could only be accessed by certain people. In addition, as a script written in tens of years ago, the ancient manuscripts are less friendly to the people later, in terms of language, literacy, and razam used. Based on this background, this article tried to reveal the contents of the Book of Issengi Majeppu (LTMM-IX) by using the philology approach. The study on the manuscript found that it was written in Bugis language with the hurufu script (pegon) of razam naskhi. Each theme of discussions mediated with basmalah and the piece is composed of several chapters. To reveal the contents, the researcher firstly carried out transliteration and translation. The Book of Issengi Majeppu is the mysticism (tasawwuf) book discussing shariat, tariqat, hakikat, and ma'rifat. Besides it slipped the knowledge of marital relationship and the knowledge of invulnerability.
\end{abstract}

Keywords: classical manuscript, manuscripts, issengi majeppu.

\section{PENDAHULUAN}

$\mathrm{N}$ askah-naskah lama banyak menyimpan sejumlah hikmat berupa nilai-nilai luhur warisan nenek moyang bangsa yang sampai sekarang masih relevan dengan kehidupan masyarakatnya (Soeratno, 1996: 22). Dengan demikian, dari tulisan-tulisan ini dapat diperoleh gambaran lebih jelas mengenai alam pikiran, adat istiadat, kepercayaan, dan sistem nilai orang pada zaman lampau, suatu pengertian yang tidak mungkin tercapai jika bahan-bahan keterangan hanya terdiri dari peninggalan material (Ikram, 1987: 3). 
Menurut Djamaris (1993: 19) banyak di antara naskah-naskah lama yang mengandung ide yang besar, buah pikiran yang luhur, pengalaman jiwa yang berharga, pertimbangan-pertimbangan yang luhur tentang sifat baik dan buruk, rasa penyesalan terhadap dosa, perasaan belas kasihan, pandangan kemanusiaan yang tinggi, dan sebagainya. Di samping itu, naskah kuno merupakan salah satu sumber informasi kebudayaan daerah masa lampau yang sangat penting.

Dalam kenyataan, masih terdapat naskah lama yang bertahan hidup bahkan berkembang pada kehidupan masyarakat masa kini. Hal ini menginformasikan beragamnya bahan yang pernah dikenal oleh bangsa Indonesia dan selanjutnya dapat mengungkapkan perkembangan pemakaian bahan bagi naskah-naskah Indonesia. Hasil studi demikian akan menginformasikan pula kemajuan berfikir dan kreativitas bangsa dalam menciptakan sarana penyampai buah pikirannya (Soemantri, 1986; Mulyadi, 1994). Lebih lanjut Ilyas (2011: 1) mengatakan bahwa naskah berkaitan erat dengan kecakapan baca tulis dan kemajuan peradaban masyarakat pendukungnya pada masa lampau, isi teks dalam naskah dapat memberikan kesaksian yang dapat berbicara langsung kepada kita melalui bahasa yang tertuang di dalam tulisan tersebut. Oleh karena itu naskah memegang peranan penting dan strategik pada hampir semua aspek kehidupan (Yusuf, 2012: 1-22).

Bertolak dari uraian di atas, pelestarian budaya intelektual berupa tulisan tangan yang terekam dalam berbagai bahan seperti bambu, kulit kayu, daun lontar, maupun kertas, sangat perlu dilakukan mengingat perkembangan kebudayaan Indonesia dapat dipahami melalui kajian-kajian naskah lama. Demikian pula dengan pandanganpandangan serta cita-cita yang menjadi pedoman hidup nenek moyang kita, tertuang di dalam naskah klasik tersebut (Hinta, 2005: 26-28).

Pradotokusumo (1984:60) mengatakan bahwa suatu karya yang berwujud teks dan tertulis dengan bahasa yang khas itu tidak akan berfungsi jika tidak ada pembacanya yang menjadi penyambut, penafsir, dan pemberi maknanya. Sanwani mengatakan bahwa di Perpustakaan Nasional RI di Jakarta terdapat kurang lebih 10.000 naskah. Semua itu adalah peninggalan tertulis (tulisan tangan) nenek moyang bangsa Indonesia. Naskah tersebut ditulis pada daun lontar, kulit kayu, rotan, bambu, nipah, dan kertas. Peninggalan bersejarah suatu bangsa yang dapat memberikan kejelasan mengenai sejarah dan kebudayaan bangsa tersebut, merupakan karya lama yang tertulis dalam berbagai huruf dan bahasa daerah di mana naskah itu lahir.

Perhatian para peneliti naskah di Indonesia terhadap naskah-naskah tersebut belum signifikan bila dibandingkan dengan jumlah naskah yang ada. Padahal kalau mau ditelusuri lebih jauh naskahnaksh tersebut mengandung nilai-nilai yang begitu berarti, karena dengan membaca naskah tersebut maka generasi sekarang dapat mengetahui bagaimana intelektual, kapan dan dimana naskah tersebut dibuat.

Selain naskah-naskah yang ada pada perpustakaan Nasional, tak disangkal bahwa masih banyak naskah-naskah yang ada di tangan masyarakat. Salah satu diantaranya adalalah Issengngi Majeppu, naskah ini belum pernah didata atau belum digarap oleh para peneliti, khususnya peneliti naskah. Bahkan menurut informasi dari pemiliknya, naskah tersebut belum terkatalog. Judul naskah ini diberikan oleh penulis, nomor kode LTMM-IX yang diberikan oleh pemiliknya. Issengngi Majeppu diambil dari kata pertama naskah tersebut. Naskah ini terdiri dari 135 halaman dengan huruf hijaiyah (huruf Serang), kitab ini berisi tentang syariat, thariqat, hakikat, dan ma'rifat.

Banyak kendala yang dihadapi dalam mentransfer ilmu pengetahuan yang ada dalam naskah. Salah satu kendalanya adalah masalah huruf dan bahasa yang digunakan naskah tersebut. Melihat kenyataan tersebut, maka para peneliti berusaha mentransliterasi dan menterjemahkan naskah-nasakah tersebut ke dalam berbagai bahasa. Naskah yang menjadi fokus penelitian yaitu naskah Issengngi Majeppu, koleksi Abdul Muis Mandra dengan kode LTMM-IX.

Berdasarkan latar belakang di atas, tulisan ini mengemukakan pertanyaan penelitian, yaitu: Bagaimana deskripsi naskah Issengngi Majeppu kode LTMM-IX? Dan apa isi kandungan naskah Issengngi Majeppu kode LTMM-IX tersebut?.

Tulisan ini bertujuan untuk mengetahui deskripsi naskah Issengngi Majeppu kode LTMMIX dan untuk mengetahui isi kandungan naskah Issengngi Majeppu kode LTMM-IX.

\section{Tinjauan Pustaka}

Belum ada kesepakan di antara para ahli kapan tradisi tulis dimulai di Sulawesi Selatan dan Sulawesi Barat. Namun demikian beberapa ahli memastikan bahwa tradisi sudah dimulai jauh sebelum agama Islam masuk ke Sulawesi Selatan, atau sebelum tahun 1600, hal ini telah dibuktikan melalui situstu- 
bata tertulis di Somba Opu. Masuknya Islam di Sulawesi Selatan sangat penting dijadikan patokan karena pada umumnya cerita kuno Sulawesi Selatan dan Sulawesi Barat menuturkan berbagai kisah yang sama sekali tidak menyinggung masalah Islam. Jika diperhatikan scope Spacial yang dikisahkan berbagai kisah-kisah kuno Bugis yang dikenal dengan nama Galigo, tampak dengan jelas bahwa kandungan ceritanya menyangkut zaman penghujung abad ke-14 hingga awal abad ke-17, pada periode awal masuknya Islam di Sulawesi Selatan.

Namun demikian perkiraan abd ke-14 mulai titik perhatian, karena ketika itu nama-nama seperti Majapahit muncul dalam pengkisahan dan banyak disinggung dalam lontara-lontara Bugis. Jika sekiranya kisah-kisah kuno Bugis telah ditulis sebelum abad ke-14, maka tentulah bukan Majapahit yang disebutnya. Dengan demikian dapat diduga bahwa lontara-lontara kuno Bugis telah ditulis dalam rentang waktu yang panjang, paling tidak dari abad ke-14 hingga awal abad ke-17. Hal ini dibuktikan dengan ditemukannya naskah Galigo (Rol 41, N0. 9) di Luwu berjudul: Lontara Purukani Asellengeng (Islam). Penulisan kisah yang melalui perjalanan sejarah dalam rentang waktu yang panjang ini, menjadikan kisah yang termuat di dalamnya sangat kaya dengan berbagai legenda dan informasi sejarah. Naskah-naskah semacam ini sangat penting artinya bagi studi sosial kemasyarakatan. Karena melalui naskah-naskah ini dapat diperoleh pengetahuan tentang fluktuasi kehidupan yang dialami suatu masyarakat.

Perubahan-perubahan bentuk tatanan sosial kemasyarakatan di Sulawesi Selatan dan Sulawesi Barat tidak sekedar terjadi sebagai perubahan biasa, tetapi sebenarnya perubahan itu menandai terjadinya suatu pergantian tatanan kemasyarakatan, kehidupan sosial politik secara ideologi yang dianut secara total. Perubahan ini sangat besar artinya, karena yang berubah bukan hanya simbol dan perlambang dalam masyarakat. Perubahanperubahan seperti ini tidak hanya berguna untuk studi naskah dan studi terhadap karya tulis yang lahir dalam masa perubahan-perubahan itu, tetapi juga satu studi tentang panorama kehidupan masa lampau yang masih dapat ditangkap oleh orang yang mau memahami kearifan sejarah masyarakatnya.

Selain naskah tersebut di atas, terdapat naskahnaskah klasik di Sulawesi Selatan dan Sulawesi Barat yang memuat tentang terjadinya suatu perubahan besar dalam kehidupan masyarakat baik dari sistem kepercayaan maupun terhadap tatanan sosial politiknya, seperti naskah Galigo ri Gilinna Sanapatie yang menceritakan tentang suatu masa di Luwu (tana Ugi) sesudah raja lahir (Sawerigading) tinrille (tenggelam) di sungai Cerekang menuju Uri Liu (dunia bawa), maka terjadilah kekosongan pemerintahan di Alekawa (Andi Zanal Abidin, 1999: 56). Periode inilah cikal bakal dari perubahan kehidupan masyarakat di Sulawesi Selatan dan Sulawesi Barat. Paeni (2003) mengistilahkan dengan masa pencerahan, karena nama-nama perilaku yang ada dalam naskah tersebut, sebahagian sudah menggunakan nama-nama Islam, seperti Borahima (Ibrahim), Semaila, Sumaila (Ismail), Jiberele (Jibril), Hammadong (Ahmad).

Dalam perkembangan selanjutnya, ajaran Islam mempengaruhi naskah-naskah klasik baik dari aspek kepercayaan, kesusasteraan, dan sosial kemasyarakatan lainnya. Pada aspek kepercayaan sudah mulai berubah dari animisme-dinamisme ke Islam; sedang pada aspek kesusasteraan juga mengalami pengaruh yang besar seperti syair-syair sudah mulai mengadopsi ajaran-ajaran Islam, pada aspek sosial kemasyarakatan terlihat terutama pada acara-acara perkawinan dan adat istiadat lainnya,

Penataan masyarakat dalam kerajaan-kerajaan lokal di Sulawesi Selatan dan Sulawesi Barat mengalami masa kemarakan dalam abad ini, sejak datangnya tomanurungsebagai konseptor kekuasaan yang membangun negeri-negeri menjadi kerajaankerajaan yang lebih luas wilayah teritorialnya dan semakin banyak pula petugas penyelenggaraan kekuasaannya atas rakyat yang semakin banyak pula jumlahnya, memerlukan penataan masyarakat lebih baik pula. Pangaderreng merupakan konsep dasar dalam penataan masyarakat Sulawesi Selatan dalam kerajaan-kerajaan lokal masing-masing. Pangaderreng sebagai aturan-aturan adat, sistem norma, dan tatanan nilai yang sangat ideal, yang berlaku bagi masyarakat Bugis-Makasar sebagai pandangan hidupnya secara timbal balik terhadap pranata sosial lainnya. Pangaderreng mempunyai empat unsur, yakni: ade, bicara, rapang, dan wari. Setelah datangnya Islam, maka masuklah sara' (syariat Islam) sebagai unsur kelima yang mewarnai atau mendominasi dan bahkan menjadi penyempurna dari keempat unsur yang ada dalam pangaderreng, demikian halnya di Mandar, setelah datangnya Islam dikenal istilah Punggawa Sara' dan Puakkali.

Di sisi lain, perkembangan naskah klasik seiring dengan perkembangan tradisi besar yang 
mengemukakan di atas, beragam naskah tersimpan di istana dan rumah-rumah bangsawan tinggi serta pembesar kerajaan di pusat-pusat kekuasaan tradisional, pada zaman ini berlangsung sekitar tiga abad lamanya. Naskah klasik menjadi sumber berbagai ilmu pengetahuan dibaca dan dipelajari oleh para intelektual zamannya. Kutika (berisi tentang perhitungan hari, baik dan buruk), misalnya tidak hanya memuat berbagai ramalan tentang hari baik dan buruk atau tentang nasib peruntungan, tetapi juga membicarakan tentang pertanian. Naskah semacam ini sangat penting artinya dalam tatanan kehidupan masyarakat yang dikenal sebagai masyarakat agraris, begitu juga terhadap kehidupan nelayan dan perantau (passombal-passompe-pallopi) dalam menentukan arah dan tujuan ke mana hendak berlabu.

Naskah klasik khususnya kutika yang memuat astrologi tradisional ditulis berdasarkan pengalaman yang berulang-ulang yang cukup lama. Ketika tradisi besar itu runtuh, sejak saat itu tidak pernah ada lokal scholar yang mencurahkan hidupnya untuk mengamati gejala dan perubahan alam dan merevisi kembali naskah-naskah yang tidak sesuai lagi. Namun, perkembangan lain dari naskah yang memuat tentang jenis-jenis penyakit dan resep pembuatan obat mengalami kemajuan, sama halnya dengan naskah-naskah yang memuat tentang teknilogi pembuatan benteng-benteng kerajaan dan teknologi persenjataan, yang ketika itu menjadi prioritas utama bagi sistem pertahanan pantai yang dikenal dengan lontarak ba'dili lompo milik kerajaan Gowa abad ke-17 (Paeni, 2003).

Naskah-naskah sumber ilmu pengetahuan semacam ini pada umumnya hanya dimiliki oleh pendukung tradisi besar di puast-pusat kekuasaan, akan tetapi ajak runtuhnya kerajaan-kerajaan besar di Sulawesi, atau masuknya dominasi asing pada abad ke-17 hingga awal abad ke-20, yang berlangsung kurang lebih 2,5 abad. Naskah-naskah klasik yang memuat berbagai informasi tentang iptek bunga rampai budaya dan agama berpindah tangan ke generasi pewaris kekuasaan tradisional yang lebih rendah tingkat sosialnya, mereka hidup secara terpisah-pisah di berbagai kerajaan-kerajaan kecil atau pada keturunannya di pusat kekuasaan kolonial.

Ketika penguasa kolonial Belanda melakukan ekspedisi penaklukan di awal abad ke-20 terhadap kekuasaan tradisional di Sulawesi dan akan diterapkan satu sistim kontrol kekuasaan, pusat kekuasaan tradisional yang ada di Sulawesi porak poranda, ketika itulah terjadi lagi degredasi pemilik naskah. Selain itu naskah-naskah yang ada oleh pihak kolonial dirampas dan disita lalu dikirim ke negaranya sebagai bahan atau informasi tentang adat dan sosial kemasyarakatan, sehingga naskah-naskah klasik tersimpan dengan baik bahkan cenderung disakralkan, bahkan naskah merupakan simbol status bagi pemiliknya sehingga naskah tersebut tidak bisa dibuka atau dibaca secara langsung untuk membukanya diperlukan berbagai syarat tertentu (Idham, 2011).

Pada posisi seperti itu, sebuah naskah sulit untuk didekati apalagi dibaca, disentuh pun harus melalui berbagai persyaratan. Hal seperti ini merupakan kasus yang seringkali ditemukan dengan berbagai cerita dan keunikan serta keakralan naskah tersebut, meskipun isi dan kandungannya hanya merupakan pangajaran fiqih, kisah nabi, dan sahabat-sahabatnya, atau cerita klasik lainnya.

Naskah-nasakah klasik Islam di Sulawesi, selain memuat ajaran-ajaran Islam dari segi ibadah dan muamalah, juga memuat tentang sejarah Islam, maupun pelaku sejarah Islam yang berkaitan dengan penyebaran Islam. Harus diakui bahwa ternyata naskah-naskah klasik Islam di Sulawesi masih banyak yang belum terinventarisasi terutama yang dimiliki orang perseorangan di berbagai pelosok pedalaman Sulawesi, dan bahkan yang sudah terinventarisasi pun mengalami berbagai kendala dalam pelestariannya karena kurangnya minat dan kemampuan generasi kaum terpelajar untuk membaca dan mengkaji naskah-naskah tersebut.

\section{METODE PENELITIAN}

Dalam penelitian filologi, ada tujuh tahapan yang perlu diperhatikan, yaitu: 1) pengumpulan naskah, 2) mendeskripsikan naskah-naskah, 3) perbandingan naskah, 4) pertimbangan naskah, 5. penentuan naskah yang autoritatif dengan menerapkan metode obyaktif, 6) suntingan teks, dan 7) transliterasi (Hinta, 2005: 26-28; Ikhwan, 2009: 377).

Metode penelitian filologi yang dilakukan menggunkan naskah tunggal kemudian deskripsi, transliterasi, dan terjemahan naskah.

Pengolahan dengan menggunakan metode deskriptif. Naskah Kitab Issengngi Majeppu, mulai dari nomor naskah, judul naskah, kode naskah, asal naskah, bahasa naskah, ukuran naskah, ukuran teks, keadaan naskah, tebal naskah, jumlah halaman, dan lain-lain. Selanjutnya adalah metode transliterasi dan menerjemahkan ke dalam bahasa Indonesia 
serta mengklasifikasi isi kandungan naskah tersebut.

Tahap transliterasi adalah penyalinan dengan penggantian huruf dari abjad yang satu ke abjad yang lain (Depdikbud, 2002: 1209). Transliterasi dimaksudkan sebagai penggantian jenis tulisan, huruf, dan abjad ke abjad yang lain (Djamaris, 1977: 29). Selanjutnya, Djamaris (1991: 197) juga mengatakan bahwa salah satu tugas filolog dalam transliterasi adalah menjaga kemurnian bahasa lama dalam naskah, khususnya dalam penulisan kata. Penulisan kata yang menunjukkan ciri ragam bahasa lama dipertahankan bentuk aslinya. Hal yang perlu diperhatikan sebagai salah satu pedoman dalam transliterasi adalah ejaan dan ciri khusus bahasa naskah.

Tahap penerjemahan adalah menyalin atau memindahkan suatu bahasa ke bahasa lain, mengalihbahasakan (Djamaris, 1991: 197). Terjemahan yang paling tepat ialah suatu perpindahan teks dari suatu bahasa (bahasa sumber) ke bahasa lain (bahasa sasaran) yang berpadanan (Pradotokusumo, 1998: 3). Pendapat lain mengatakan bahwa terjemahan adalah pengungkapan kembali pesan bahasa sumber ke dalam bahasa sasaran dengan padanan yang paling alamiah, yang pertama artinya, kemudian gayanya.

Terjemah dalam naskah ini digunakan dua cara, yakni terjemahan secara harfiah dan terjemahan agak bebas. Terjemahan secara harfiah adalam menerjemahkan dengan menuruti teks sedapat mungkin, meliputi kata demi kata. Metode ini sangat terikat dengan teks dan urusan katakatanya dengan tujuan menyampaikan arti teks secara tepat dan jujur. Adapun terjemahan secara agak bebas atau bebas adalah seorang penerjemah diberi kebebasan dalam proses penerjemahannya namun kebebasannya itu dalam batas kewajaran, ia menerjemahkan ide tulisan dan tidak terlalu terikat dengan susunan bahasa tersebut, baik bahasa teks maupun bahasa yang diterjemahkan ke dalamnya.

Selain terjemahan harfiah dan terjemahan agak bebas tersebut di atas, dalam penerjemahan dikenal pula terjemahan yang sangat bebas. Penerjemahan dengan sangat bebas adalah penerjemah bebas melakukan perubahan, baik menghilangkan bagian, menambah atau meringkas teks. Cara ini tidak dapat digunakan dalam menangani teks naskah klasik yang memerlukan tingkat kejujuran dan ketelitian yang tinggi (Lubis, 1996: 75; Darutasuprapta, 1985: 9)

Isi kandungan naskah, berfokus pada kajian apa saja yang terkandung dalam naskah tersebut, dalam hal ini penulis mengemukakan isi kandungan setiap bagian dan pasal yang ada. Adapun hasil transliterasi dan terjemahan menjadi dokumen arsip penulis, karena yang di paparkan dalam tulisan ini hanyalah isi kandungan naskah yang sudah dibagi dalam beberapa bagian dan pasal.

\section{PEMBAHASAN \\ Deskripsi Naskah Issengngi Majeppu Kode LTMM-IX}

Naskah Kitab Issengngi Majeppu Kode LTMMIX ditemukan di Kecamatan Sendana Kabupaten Majene Provinsi Sulawesi Barat. Pemilik naskah adalah Abdul Muis Mandra, seorang budayawan Mandar. Beliau memperoleh naskah ini tahun 1950an dan tahun 60-an. Naskah ini merupakan hasil foto copy, maka informasi tentang kertas tidak bisa dikemukakan. Menurut Muis Mandra, naskah ini diperolehnya di wilayah Majene, kitab ini dibawah oleh orang-orang Mandar yang belajar agama di daerah Bugis (khususnya pulau Salemo). Naskah aslinya sudah tidak diketahui keberadaannya.

Dari sekian banyak koleksi Muis Mandra (dengan kode LTMM), sebahagian besar dalam bentuk foto copy. Menurut pengakuannya, naskah sangat sukar diperoleh karena sebahagian pemilik naskah mensakralkannya. Lanjutnya, naskah yang diperoleh dengan cara penfotocopy juga tidak semudah yang dibanyangkan, banyak naskah yang oleh pemiliknya baru bisa dibuka dan dipinjamkan setelah ada acara ritual, berupa pemotongan satu dan atau dua ekor kambing.

Adapun deskripsi naskah dapat dilihat pada tabel berikut:

Tabel 1. Deskripsi Naskah

\begin{tabular}{cc}
\hline Uraian & Naskah \\
\hline Tempat penyimpanan & Sendana Kabupaten Majene \\
Judul & Issengngi Majeppu \\
Jenis isi & LTMM-IX \\
Bahasa & Tasawuf \\
Tanggal, tempat, dan & Bugis dan Arab \\
penyalinan & Tidak ada \\
Jumlah halaman & 135 halaman \\
Jumlah baris perhalaman & 17 baris \\
Penomoran halaman & Huruf Arab bagian pinggir \\
Huruf & atas \\
Kolom & Arab (Serang) \\
& $25 \mathrm{x} 17 \mathrm{~cm}$ \\
\hline
\end{tabular}

Adapun digitalisasi naskah, transliterasi dan terjemahan naskah ini tetap disimpan oleh penulis. Seperti yang telah dikemukakan sebelumnya, 
transliterasi dimaksudkan sebagai penggantian jenis tulisan, huruf, dan abjad ke abjad yang lain. Transliterasi sangat penting untuk memperkenalkan teks lama dengan huruf daerah (belum populis) kepada masyarakat. Proses transliterasi tetap mengacu dan memperhatikan pedoman baku yang berhubungan dengan pembagian kata, ejaan, dan punktuasi. Tulisan teks-teks lama tidak memperhatikan hal tersebut. Gaya penulisan teks lama, hanya mengalir berupa penceritaan yang mengalir, tidak ada tanda-tanda baca, seperti titik, koma, seru, tanya, dan lain sebagainya.

Melihat keadaan tersebut, penulis membagi naskah ini dalam beberapa bagian dan memberikan penomoran pasal, sementara untuk mengetahui pemisah baris digunakan tanda strep ( / ). Selanjutnya dalam proses penerjemahan, peneliti menggunakan terjemahan yang lebih condong kepada penerjemahan lafdziyah. Adapun tanda titik tiga (...) sebagai tanda bahwa naskah asli tidak bisa terbaca atau tidak bisa diartikan.

\section{Isi Kandungan Naskah Kitab Issengngi Majeppu Kode LTMM-IX}

Naskah ini setelah dicoba dibagi dalam beberapa bagian, dan setiap bagian terdiri atas beberapa pasal. Pembagian setiap bagian ditandai dengan lafal basmalah dan setiap bagian terdiri atas beberapa pasal. Setelah dikaji, naskah ini terdiri atas delapan bagian dan 69 pasal. Berikut ini dikemukakan isi kandungan setiap bagian dan pasal.

\section{Bagian bertama terdiri atas dua pasal.}

Bagian ini diawali seruan agar pembaca mengetahui secara benar tentang syariah, tarekat, hakekat, dan ma'rifah. Syariah adalah segala yang diperintahkan oleh Allah dan bagaimana tata cara penyembahan; tarekat adalah diketahuinya jenis perintah Allah dan menghadirkan pemberi perintah itu di dalam hati; hakekat adalah sampainya tujuan persaksian hamba kepada Allah swt. Dicontohkan dalam ibadah, melakukan shalat itu adalah syariat, menetapan Allah dalam perbuatan shalat adalah tarekat, dan apabila shalat itu sampai kepada Allah itulah hakekat; sedangkan ma'rifah adalah pemahaman akan hakekat, pemahaman tentang Yang Esa, Allah Swt. Pada bagian ini disebuykan salah satu ungkapan yang lazim bagi ahli tarekat: man 'arafa nafsahu faqad 'arafa rabbahu (siapa yang mengenal dirinya, maka dia mengenal Tuhannya).

\subsection{Pasal No. 1}

Pasal ini menjelaskan tentang shalat bagi orang yang meninggal, mengapa harus empat takbir dan tanpa rukuk, tanpa sujud, dan tanpa duduk. Dijelaskan, alasan sehingga pada shalat orang yang meninggal dilakukan demikian karena orang matilah yang diganti untuk menyembah Allah swt. Menyalati itu sangat perlu dengan memperhatikan tujuh cara, yaitu: pertama niat, kedua berdiri, ketiga takbir, keempat membaca fatihah setelah takbir, kelima membaca shalawat setelah takbir, keenam memberi salam dan ketujuh tertib. Selanjutnya pada pasal ini dijelaskan bahwa orang yang tidak mengetahui perkara ini tidak dapat disebut guru.

\subsection{Pasal No. 2}

Pasal ini menjelaskan apabila anda ditanya mengapa shalat jenazah 4 takbirnya. Dijelaskan alasan sehingga dalam shalat jenazah itu 4 rakaat karena Nabi Adam diciptakan dari empat unsur, yakni: air, tanah, angin, dan api.

\section{Bagian kedua terdiri atas delapan pasal}

Pada bagian ini dijelaskan makna dari shalat lima waktu, shalat Subuh dialah sifat yang ada pada diri, adapun shalat Dhuhur dialah yang punya perbuatan, adapun shalat Ashar ialah dirinya sendiri, adapun shalat Magrib dia yang utama, adapun shalat Isya dialah yang besar. Adapun shalat witir dialah yang dicari dan dialah yang menyembah dirinya sendiri. Tak lupa dipaparkan resiko atau ganjaran bagi mereka yang meninggalkan shalat lima waktu, yakni apabila meninggalkan shalat Subuh berarti orang itu telah hilang keimanannya, apabila meninggalkan shalat Dhuhur berarti ia tidak disinari Alqur'an, bila meninggalkan shalat Ashar akan dijauhi para malaikat, bila meninggalkan shalat Maghrib hilanglah segala pahalanya, dan bila meninggalkan shalat Isya maka hilanglah seluruh rezkinya.

\subsection{Pasal No. 1}

Pasal ini menjelaskan tata cara memandikan orang mati, dan sebab-sebabnya mengapa orang mati dimandikan.

\subsection{Pasal No. 2}

Pasal ini menjelaskan tentang pertanyaan yang diajukan oleh Mungkar di alam kubur dan menjelaskan bagaimana jabang bayi selama dikandung (sembilan bulan) dalam kandungan. Pada pasal ini juga dijelaskan waktu dan proses penciptaan panca indera manusia. 


\subsection{Pasal No. 3}

Pasal ini yang menjelaskan awal mula keinginan nyawa masuk ke dalam tubuh. Ada dialog antara nyawa dengan Allah. Allah berkata hai nyawa maukah engkau memperistrikan tubuh, berkatalah nyawa saya mau Tuhan. Kemudian Allah berkata lagi hai tubuh maukah engkan mempersuamikan nyawa, maka tubuh mengatakan saya inginTuhan. Maka Allah berkata hai nyawa apa yang pengikatnya tubuh, maka nyawa berkata ketaaatan yang sebenarnya bersama kesabaran yang harus dipahami. Allah Swt bertanya kepada nyawa, siapa yang menikahkanmu, nyawa menjawab ucapan yang menikahkanku, Allah bertanya lagi siapa saksimu? dan seterusnya.

\subsection{Pasal No. 4}

Pasal ini menjelaskan Nabi Muhammad Saw dan dialog nabi Nabi Khaidir dengan Nabi Muhammad Saw. Pada pasal ini juga dijelaskan dialog antara nyawa dengan Allah swt, hingga bayi tersebut dapat dilahirkan oleh ibunya. Pada akhir bab diinformasikan bahwa setelah bayi cukup sembilan bulan, Allah swt memerintahkan bayi untuk keluar dari perut ibunya untuk mengisi dunia ini, dan dipesankan agar bayi tersebut jangan sekalikali berpisah dengan Al Fatihah, Surah Al Ikhlas, dan beberapa bacaan lainnya.

\subsection{Pasal No. 5}

Pasal ini menjelaskan tentang hakekat Shalat, yakni ditegakkan oleh Alif, diruku'kan oleh Ha, disujudkan oleh Mim, dan duduk itu Dal. Apabila telah berdiri untuk melakukan shalat, maka niatkanlah yang berdiri itu Alif. Jika telah mengucapkan Usalli maka satukanlah fikiran itu kepada Allah Swt, jika telah dikatakan Farda Dhuhri maka fikiran itu telah bersama dengan Tuhanku dan berbisik-bisik kepada Tuhan. Jika telah membaca Fatihah, maka menyatulah fikiran kita kepada Allah, jika telah membaca surat yang lain kita seperti Nabi Muhammad Saw, maka niatkanlah diri kita adalah Ha maka fikiran itu membesarkan Tuhan Jika telah mengucapkan "Samiallahu Liman Hamidah" maka fikiran itu telah diketahui oleh Allah dan juga didengarkan-Nya. Jika sujud niatkanlah dirimu sebagai Mim maka fikiran itu berkata tiada Tuhan selain Allah swt. Jika duduk, niatkanlah dirimu sebagai Dal maka berkatalah fikiran kita tidak ada yang lain selain Allah Swt. Jika memberi salam maka takut dan malulah kepada Allah. Jika telah selesai melakukan shalat maka niatkanlah pahala shalat kita disimpan di Nur Muhammad. Nur Muhammad yang menyampaikannya kepada Allah Swt. Jika membaca doa maka diniatkan lagi diri kita berada di ka'bah membaca doa. Demikianlah tertibnya shalat.

\subsection{Pasal No. 6}

Pasal ini menjelaskan tentang perkataan Abdul Kadir Jaelani. Abdul Kadir Jaelani mengajarkan apabila berdiri melakukan shalat maka niatkanlah dirimu sebagai Alif, dan serahkanlah nyawa kepada Allah swt karena itulah penglihatan yang tidak putus terhadap Allah swt.

\subsection{Pasal No. 7}

Pasal ini menjelaskan jika ingin kembali kepada Allah maka hendaklah memandikan diri terlebih dahulu. Pada pasal ini juga dibicarakan tentang tingkatan Dzikir, yakni La Ilaha Illallah, Allah Allah, Huwa Huwa dan dzikir rahasia A A A.

\subsection{Pasal No. 8}

Pasal ini menjelaskan tentang Keesaan Allah Swt, juga dijelaskan empat tingkatan dalam mengesakan Allah swt. Pasal ini ditutup dengan salah satu ayat yang berbunyi: huwal awwalu wal akhiru wa dhahiru wal bathinu (Dialah Allah yang awal, Dialah yang akhir, Dialah yang dhahir (nyata), Dialah yang tersembunyi).

\section{Bagian ketiga terdiri atas empat pasal}

Pada bagian ini dipaparkan masalah taubat dan dzikir. Adapun lafadz taubat adalah "astaghfiru allah alladzi la ilaha illa huwa al hayyu al qayyum wa atubu ilaihi wa la quwwata illa bi allahi al aliyyi al adhim. Hal ini bagus dilakukan sekurang-kurangnya 100x sehari semalam jika mampu dilakukan maka lakukanlah, semakin banyak dilakukan semakin bagus. Selain itu dipaparkan juga keutamaan dzikir La Ilaha Illallah.

\subsection{Pasal No. 1}

Pasal ini menjelaskan tentang huruf dalam shalat. Ada empat huruf dalam shalat, huruf yang pertama huruf Alif, kedua huruf $\mathrm{Ha}$, ketiga Mim dan keempat Dal. Adapun Alif pada saat berdiri dan hakekatnya ada pada diri sendiri, yakni dzatnya Allah Swt. Adapun huruf Ha yaitu pada saat ruku' yang menunjukkan sifat-Nya Allah Swt ada pada diri kita, Huruf Mim pada saat kita sujud, maka hati kita dinamakan Allah adapun Dal, pada saat duduk.

\subsection{Pasal No. 2}

Pasal ini menjelaskan tujuan shalat lima waktu. Selain itu dijelaskan pula maksud dari bacaan dalam shalat, seperti membaca surah Al Fatihah. Al 
Fatihah berarti pembuka. Disini dijelaskan pula ada lima yang menjadi pembuka, yakni pada pertama perkataan, kedua penglihatan, ketiga pendengaran, keempat penciuman, dan kelima perasaan. Itulah hakekatnya lima waktu. Pada pasal ini dikemukakan tidah sah shalat seseorang kecuali membaca surah $\mathrm{Al}$ Fatihah (la shalata illa bil fatihah). Pasal ini ditutup dengan ungkapan al insanu sirri wa ana sirruhu (manusia itu rahasiaku, dan Sayalah rahasianya).

\subsection{Pasal No. 3}

Pasal ini menjelaskan tentang waktu-waktu shalat, yang menurut naskah ini setiap waktu shalat adalah milik nabi tertentu. Seperti shalat Dhuhur untuk Nabi Ibrahim, shalat Ashar untuk Nabi Yusuf, shalat Maghrib untuk Nabi Musa, shalat Isya untuk Nabi Musa, shalat Subuh untuk Nabi Muhammad.

\subsection{Pasal No. 4}

Pasal ini menjelaskan tentang perintah shalat oleh Nabi Muhammad saw. Apabila engkau telah berdiri melakukan shalat maka syaratkanlah dirimu sebagai Alif, engkau hilangkan dirimu dalam dzatnya Allah swt. Jika engkau telah mengetahui kedatanganmu dari Allah swt dan juga kembalimu, maka selamatlah engkau di dalam kuburmu.

\section{Bagian keempat terdiri atas 35 pasal}

Bagian ini menjelaskan tentang bahasa tubuh bagian di dalam dan tubuh bagian di luar. Ada tujuh pada bagian dalam dan juga tujuh pada bagian luar. Adapun tubuh bagian dalam yakni: 1) ahdiyah, 2) wahdah, 3) wahdiyah, 4) arwah, 5) alam mitsal, 6) alam ajzam, dan 7) alam insan. Adapun tubuh bagian luar yakni: 1) hati, 2) nyawa, 3) rahasia (hakekat), 4) syariah, 5) tarekat, 6) hakekat, dan 7) márifah. Adapun tubuh yang paling dalam itulah 'tubuh halus'.

\subsection{Pasal No. 1}

Pasal ini menjelaskan tentang "nafas". Roh Idhafih yang tinggal pada Sulbiyah itulah yang mengerakkan tubuh. Roh Nabati yang tinggal di pusat, yang menggerakkan hati. Roh Al A'lam yang tinggal di buah yang menggerakkan nyawa, Roh Kudus yang tinggal yang tinggal di kepala yang menggerakkan rahasia (hakekat), dan Roh Haq yang tinggal di nafas yang menggerakkan nafas yang dinamakan "Cahaya Allah (Nurun Allah) yang tinggal pada diri Allah Swt itulah yang menciptakan alam ini bersama isinya sehingga dinamakan "Cahaya Allah' (Nurun Allah) itulah sebabnya dikatakan Allahu Nurun Samawati wal Ardhi.

\subsection{Pasal No. 2}

Pasal ini menjelaskan perkataan Nabi Muhammad saw tentang orang yang dirahmati oleh Allah swt.

\subsection{Pasal No. 3}

Pasal ini menjelaskan tentang pemahaman yang sebenarnya. Maka hadapkanlah hati kita pada perbuatan yang menguntungkan (bermanfaat). Apabila engkau ingin mengetahui pemahaman yang sebenarnya kepada Allah swt maka tetapkanlah penghadapanmu kepada Tuhanmu, karena barangsiapa yang tidak mengetahui tentang TuhanNya maka kafirlah ia. Oleh karena itu ketahui dan pahamilah yang esa itu, ketahui dan pahamilah pula yang menyeruhmu untuk mengesakan-Nya, ketahui dan pahami pula orang yang menyembah itu dan juga yang disembah. Pahamilah pula yang menyembah, dan yang engkau sembah.

\subsection{Pasal No. 4}

Pasal yang menjelaskan tentang gelar sebutan diri kita (anggota tubuh kita). Adapun asalnya yang pertama perbuatan, kedua perkataan, ketiga fikiran. Adapun perbuatan yang paling baik itulah orang yang melakukan shalat, dan perkataan yang paling baik selalu mengingat-ingat kepada Allah swt pada waktu siang maupun malam, adapun fikiran yang paling baik mengingat kepada Allah swt pada waktu siang maupun malam, apabila engaka melakukan yang pertama apa-apa yang engkau lakukan maka yakinkanlah dihatimu dengan mengatakan sesungguhnya saya dilihat oleh Allah swt dalam melakukan perbuatan itu. Jika engka berkata sesuatu apapun yang engkau katakan yakinilah dihatimu dengan bahwa sesungguhnya Allah mendengar apapun yang kita katakan. Apabila engkau berfikir, apapun yang engkau fikirkan maka yakinilah di hatimu dengan mengatakan bahwa sesungguhnya Allah swt mengetahui apa yang engkau fikirkan, demikian itulah keberhati-hatian.

\subsection{Pasal No. 5}

Pasal yang menjelaskan bahwa nyawa Muhammad dinamakan ma’rifah, nyawanya dinamakan hakekat, fikirannya dinamakan tarekat dan tubuhnya dinamakan syariah.

\subsection{Pasal No. 6}

Pasal ini menjelaskan tentang penglihatan, apabila nyawa melihat Allah swt dinamakan rahasia. Apabila melihat kepada alam dinamakan keyakinan. Apabila melihat ke akhirat dinamakan nyawa, jika melihat ke dunia dinamakan kejelasan. Apabila melihat pada diri kita dinamakan fikiran. 


\subsection{Pasal No. 7}

Pasal ini menjelaskan tentang dialog antara Allah swt dengan nabi Muhammad tentang penciptaannya.

\subsection{Pasal No. 8}

Pasal ini menjelaskan tentang perkataan (ucapan) yang pertama-tama dimasukkan ke nyawa Nabi Adam. Shalat adalah nyawa yang dijadikan Adam dan Adam sendiri diciptakan dari empat unsur, yakni: api, angin, air, dan tanah.

\subsection{Pasal No. 9}

Pasal ini menjelaskan tentang shalat lima waktu yang keluar dari huruf yang lima, yakni "A L H M D"

\subsection{Pasal No. 10}

Pasal ini menjelaskan perkataan Nabi Muhammad saw yang melarang seseorang mendatangi (untuk duduk) bersama ulama kecuali ulama tersebut memanggil datang.

\subsection{Pasal No. 11}

Pasal ini menjelaskan tentang tujuan sebenarnya yang dinamakan dengan keyakinan.

\subsection{Pasal No. 12}

Pasal ini menjelaskan apabila ditanyai oleh seseorang dengan mengatakan apa tempat keluarnya yang Satu (Esa) itu, apa pula tempat keluarnya pemahaman itu, apa pula tempat keluarnya keyakinan itu, dan juga ke asal itu dan yang menegakkannya. Maka jawablah dengan mengatakan tempat keluarnya yang Satu (Esa) adalah "Qul huwallahu Ahad". Tempat keluarnya pemahaman adalah "Allahu Shamad", tempat keluarnya ketaaan (keyakinan ) adalah "lam Yalid", tempat keluarnya asal itu "Walam Yuulad" tempat tegaknya adalah "Walam Yakun Lahu Kufuwan Ahad".

\subsection{Pasal No. 13}

Pasal ini menjelaskan syarat dari pada keyakinan. Maka hadapkanlah rahasia (hakekat) adanya Allah Swt pada dzatnya Allah swt.

\subsection{Pasal No. 14}

Pasal ini menjelaskan tentang yang menggerakan Tubuh. Perbuatan Allah swt yang menggerakkan hati itu disebut Allah swt, yang menggerakkan nyawa itu sifat-nya Allah, yang menggerakkan rahasia (hakekat) itu adalah dzatnya Allah swt.

\subsection{Pasal No. 15}

Pasal ini menjelaskan penciptaan manusia. Adapun Alif itu cahaya dzat-nya Allah swt, adapun lam cahaya sifat-nya Allah swt, adapun Ha cahaya namanya Allah swt, adapun Mim itu cahaya yang bentuknya Allah swt, adapaun Dal adalah cahaya pada dadanya Allah swt. Itulah yang disebut "Alhamdu".

\subsection{Pasal No. 16}

Pasal ini menjelaskan tingkatan dzikir, yakni La Ilaha Illallah, Huwa-Huwa, Ah Ah, dan A I U.

\subsection{Pasal No. 17}

Pasal yang menjelaskan tentang cara mengingat hati di dalam zikir. Ketahui dan pahamilah zikir yang disepakati oleh para ulama semuanya mengatakan bahwa tidak ada gunanya dzikir yang diucapkan oleh lidah "La Ilahah Illallah" apabila tidak diingat oleh hati.

\subsection{Pasal No. 18}

Pasal ini menjelaskan tentang apa yang telah disebutkan dalam hadis, bahwa sesungguhnya Nabi Adam as telah berpesan lima pesan kepada anaknya. Adapun lima pesan itu adalah: 1) jangan serakah kepada dunia karena dunia itu akan lenyap, 2) jangan memperturutkan keinginan nafsu istrimu, 3) setiap amal yang akan dilakukan hendaklah dilihat akibat dari perbuatan itu, 4) jika terbesik di dalam hatimu yang ingin menjadikanmu musuh, maka hati-hatilah, dan 5) perhatikan seluruh perbuatan yang ingin dikerjakan.

\subsection{Pasal No. 19}

Pasal ini menjelaskan tentang tempat atau alam yang dilalui makhluk yang dinamakan manusia. Pada pasal ini dijelaskan beberapa tempat (alam), yakni: Pertama dunia, kedua alam kubur, ketiga padang masyhar, keempat akhirat. Adapun kehidupan dunia ibarat orang dalam perjalanan, singgah sebentar untuk makan lalu kemudian berangkat lagi menuju ke akhirat, yang merupakan tempat yang kekal.

\subsection{Pasal No. 20}

Pasal yang menjelaskan pada saat mengatakan "Lailah Illallah", dijelaskan juga sifat 20 Allah swt. Pada bagian akhir diinformasikan bahwa kalimat yang paling mulia adalah La Ilaha Illallah Muhammadun Rasulullah.

\subsection{Pasal No. 21}

Pasal ini menjelaskan sesuatu yang dipesankan, yakni pesan pertama dengan mengatakan apa yang ada katakan itulah adanya, dan semua itu adalah 
takdirnya Allah swt, kedua peliharalah lidah dari segala ucapan terhadap semua yang dicipatakan dan peliharalah lidahmu dengan baik kepada Ulama Ahlusunnah wal Jamaiah sehingga lepas dari siksaaan Allah swt, ketiga, benarkanlah Tuhan-Mu apa yang dijanjikan-Nya yakinlah bahwa rejeki itu akan ada, keempat, persipakankah kematianmu janganlah engkau lupa pada kematian itu siang maupun malam, kelima banyak mengingat Allah Swt sesungguhnya hilanglah segala keburukan dari dirimu.

\subsection{Pasal No. 22}

Pasal ini menjelaskan tentang dzikir setelah shalat, dibacalah Fatihah untuk Muhammad dan sahabatnya Abu Bakar, Umar, Usman, dan Ali. Lalu membaca doa shalat, apabila telah selesai doa shalat itu maka rapatkanlah tangan kita pada pusat lalu mengambil dzikir "A A A A" niatkanlah yakni bahwa aliflah dipusatku ini tinggal memancar di dalam dan di luar "Ismu Jalalah" saya ambil sebagai batang tubuh di dunia sampai di akhirat, nyawaku masuk pada "Nurun", "Nurun" masuk kepada Allah swt dan diniatkan bahwa tidak ada yang demikian kecuali cahayanya Allah swt. Lalu mengambil dzikir yang empat "La Ilaha Illallah", dalam keberadaanmu Ya Tuhan Allah swt di dalam... ya Tuhan, "Huwa Huwa" di dalam pancaran-Mu lah ya Tuhan, "A A A" di dalam cahaya-Mu, ya Tuhan di dalam ketetapanMu ya Tuhan.

\subsection{Pasal No. 23}

Pasal yang menjelaskan tempat berdirinya anggota tubuh kita didunia sampai akhirat.

\subsection{Pasal No. 24}

Pasal ini menjelaskan jika telah datang perasaan lemah disaat mengetahui ajal mau akan tiba, maka bertobatlah kepada Allah swt memohon ampunan, keselamatan dari Allah swt yang lalu dan yang akan datang kecil dan besar, yang nampak dan tersembunyi.

\subsection{Pasal No. 25}

Pasal ini menjelaskan tentang tanda-tanda zakratul maut.

\subsection{Pasal No. 26}

Pasal ini menjelaskan tentang ikatannya dzikir itu. Pada saat mengatakan "La Ilaha" niatkanlah dirimu dilayakkan sebagai "Nurun Muhammad" pada zdatnya Allah swt jika telah dikatakan "Illalllah" niatkanlah dirimu berada rapat dengan "Nurun Muhammad" pada dzatnya Allah swt.

\subsection{Pasal No. 27}

Pasal ini menjelaskan keutamaan zikir yang empat dalam diri kita kepada Allah swt:: La Laha Illallah, Allah Allah, Huwa Huwa dan Ah Ah Ah.

\subsection{Pasal No. 28}

Pasal ini menjelaskan bentuknya dzikir pada saat orang akan zakratul maut.

\subsection{Pasal No. 29}

Pasal ini menjelaskan tentang i’tikadnya para aali apabila kelak akan mati maka diperlihatkanlah cahaya yang tidak bertepi.

\subsection{Pasal no. 30}

Pasal ini menjelaskan tentang penyatuan antara Allah swt dengan nabi Muhammad dalam diri kita.

\subsection{Pasal No. 31}

Pasal ini menjelaskan apabila telah shalat maka bertafakkurlah syaratkan di dalam hati kita bahwa alam dan isinya tenggelam dalam dihatiku,ditubuhku dan tubuhku tenggelam dihatiku. Hatiku temggelam di nyawaku, nyawaku tenggelam di rahasia (hakekat)ku rahasia (hakekat) ku tenggelam pada nabi Adam, pada Muhammad, pada wujud yang Satu Allah swt. Maka tahanlah nafas kita lalu menunduk kebawah hingga sampai pada bagian pusar.

\subsection{Pasal No. 32}

Pasal ini menjelaskan tentang hakekat diri. Demikian itulah maksud perkataan itu karena sesungguhnya dzat Allah swt adalah Bhatin pada nyawa Muhammad adapun Nabi Adam dhahir di nyawanya Muhammad, maka tidak berpisalahlah hatinurani, nyawa kita dan juga nyawa nabi Muhammad dan juga dzatnya Allah swt artinya tidak ada yang diketahui oleh tubuh itu, tidak ada kemampaunnya, tidak ada kehendaknya kecuali perintah-Nya lah sehingga nyawa itu bergerak.

\subsection{Pasal No. 33}

Pasal ini menjelaskan pesan nabi Muhammad saw kepada anaknya, Fatimah: saya menjadikanmu anak didunia dan juga menjadikanmu anak diakhirat.

\subsection{Pasal No. 34}

Pasal ini menjelaskan tentang pesan nabi Muhammad kepada fatimah dalam hal persangkaan kepada Allah.

\subsection{Pasal No. 35}

Pasal ini menjelaskan tentang perkataan yang ditanyakan oleh Tuhan kepada orang yang 
bersumpah kepada orang (Petta) orang yang tidur.

\subsection{Pasal No. 36}

Pasal ini menjelaskan tentang perkataan Nabi Muhammad saw, Hai umatku ketahui dan pahamilah dirimu.

\subsection{Pasal No. 37}

Pasalnya ini yang menjelaskan tentang cerita nyawa di dalam tubuh.

\subsection{Pasal No. 38}

Pasal yang menjelaskan tentang pemahaman anggota tubuh, tubuh, hati, nyawa rahasia.

\section{Bagian kelima terdiri atas delapan pasal}

Bagian ini memaparkan tentang diri kita yang empat macamnya pertama tubuh, kedua hati, ketiga nyawa keempat rahasia,

\subsection{Pasal No. 1}

Pasal ini menjelaskan tentang cara bertafakkur.

\subsection{Pasal No. 2}

Pasal ini menjelaskan tentang hakekat sebenarnya shalat itu Bicara hakekat pertamanya shalat itu, jika ingin berdiri untuk shalat, setelah Alif berdiri barulah engkau berdiri untuk shalat karena Aliflah yang berdiri untuk shalat. Artinya setelah nafas kita naik baru kita berdiri untuk shalat, artinya setelah nyawa berdiri juga baru berdiri tubuh kita.

\subsection{Pasal No. 3}

Pasal ini menjelaskan tentang tujuan keluar dan masuknya nafas itu pada siang dan malam.

\subsection{Pasal No. 4}

Pasal ini menjelaskan cara (pakaian)-nya Fatimah jika hendak bertemu dengan Ali.

\subsection{Pasal No. 5}

Pasal ini menjelaskan tentang perkataan Lukmanul Hakim.

\subsection{Pasal No. 6}

Pasal ini menjelaskan tentang perkataan Nabi Muhammad saw, bagi mereka yang melihat "Mahrunnubuwah" setelah melaksanakan shalat.

\subsection{Pasal No. 7}

Pasal ini menjelaskan pembicaraan tentang tanda-tandanya Nabi Muhammad dinamakan "ashabul Kahfi". Dan diakhir bab ini dipaparkan ilmu kebal:

Iyanae I Paddisenngen akebbengeng nuurun Muhammad angka mallebbang rilaleng risaliweng nasalepuriwi matanna essoe kabbang rilaleng ri saliweng "A, $I, U$ ", alepu'naka lolang ri lino kuwa lipuki manengngi ri sininna ri pancajie ri Allah tảala.

Inilah pengetahuan tentang kekebalan (ilmu kebal)Nurun Muhammad ada memancar di dalam maupun di luar, yang menyelimuti matahari maka aku akan kebal di dalam dan di luar (aa, ii, uu), akulah yang berjalan di dunia yang menyelimuti semua yang diciptakan oleh Allah swt.

\subsection{Pasal No. 8}

Pasal yang menjelaskan sesungguhnya dinamakan diamnya hati adalah penghadapan kepada hakekat nyawa orang itu datang dari sisinya hati karena sesungguhnya hati itu adalah pintu nyawa bagi setiap orang.

\section{Bagian keenam terdiri atas delapan pasal}

Bagian ini memaparkan bahwa sebelum adanya alam ini pada mulanya yang diciptakan oleh Allah swt adalah nyawa Muhammad, pada bagian ini juga dipaparkan dialog antara Allah dengan nabi Muhammad dalam proses penciptaannya.

\subsection{Pasal No. 1}

Pasal ini menjelaskan tentang penyembahan, di dalamnya dibahas dialog antara Muhammad dengan Allah. Salah satu cuplikan dialoh itu adalah: Allah swt berkata: Hai Muhammad itulah penyembahan rahasia (hakekat) itu pada saat mengatakan "A" sedangkan nyawa bagaimana penyembahannya, Allah berkata pada saat nyawa mengatakan "I", hati mana penyembahannyakepada$\mathrm{Mu}$ ya Tuhan. Allah swt berkata Hai Muhammad penyembahannya hati pada saat mengatakan " $U$ " lalu bertanya lagi Muhammad kepada Allah, ya Tuhan bagaimana penyembahannya perumpamaan itu Tuhan, Allah swt berkata: hai Muhammad penyembahannya perumpamaan itu pada saat mengatahan "Ha" Lalu Muhammad bertanya lagi kepada Allah swt bagaimana penyembahan akal itu kepada Tuhan, Allah swt berkata hai Muhammad penyembahannya akal itu pada saat mengatakan "Hi", lalu Muhammad kembali bertanya kepada Allah swt bagaimana penyembahan bayang-bayang itu kepadamu ya Tuhan, Allah awt berkata: hai Muhaammad penyembahan bayang-bayang itu pada saat mengatakan "Hu".

\subsection{Pasal No. 2}

Pasal ini menjelaskan kepada Muhammad bahwa sesungguhnya kejelasan rahasia itu adalah "Aa", kejelasan nyawa itu adalah "ii", kejelasan hati adalah "Uu", kejelasan perumpamaan itu adalah "ha”, sedangkan Kejelasan akal adalah "Hi”, kejelasan 
bayang-bayang itu adalah "Hu" dan kejelasan Alif itu adalah perasaan.

\subsection{Pasal No. 3}

Pasal ini menjelaskan bahwa ketahui dan pahamilah secara jelas Alif dan artinya Alif itu dan juga asal dari Alif itu. Alif hanya sebuah titik (.). Adapun segala sesuatu yang berasal dari titik (.) pada waktu menetesnya titik (.) itu melahirkan empat tanda pertama baris di atas, kedua baris di bawah, ketiga damma, keempat adalah titik, pada waktu dibagi maka jadilah empat huruf pertama huruf "Alif" kedua huruf "Lam pertama", ketiga "Lam kedua", keempat huruf "Ha" itulah lafadznya "Allahu".

\subsection{Pasal No. 4}

Pasal ini menjelaskan nyawa Muhammad dinamakan Ma'rifah, Nyawa kita dinamakan hakekat, fikiran kita dinamakam tarekat, tubuh kita dinamakan syari'ah, maka ketahuilah sesungguhnya dirimu yang ada pada tubuhmu.

\subsection{Pasal No. 5}

Pasal ini menjelaskan tentang nyawa itu melihat pada Allah swt itulah rahasia (hakekat) jika melihat pada alam maka dinamakan keyakinan , jika melihat akhirat dinam akan nyawa, jika melihat dunia maka dinamakan diri (tubuh kita) jika melihat pada dirinya dinamakan Al'ilmu Juhulun Wa Alma'rifatu Inkarun Wa Attauhidu Al Tijaru artinya pengetahuan kepada Allah swt adalah kebodohan atas segala sesuatu. Sedangkan pemahaman kepada Allah swt pada saat oleh diri kita adapun pengesaan kepada Allah swt adalah kekeliruan.

\subsection{Pasal No. 6}

Pasal yang menjelaskan tentang tarekatnya para wali, setelah dzikir, tambahkan setelah berdzikir, ditahanlah nafas itu dan ditariklah "LA" yang keluar dari pusat kita lalu ditarik pula "Ilaha" naik, di atas ujung siku. Apabila dikatakan "Illallah" maka ditancapkanlah dalam hati sanubari, jika telah bershalawat maka diyakinilah bahwa nabi Muhammad ada di depan kita dan lalu beliau dishalawatkan secara tetap, lalu Nabi mendengarkan shalawat itu semoga berkahnya kembali.

\subsection{Pasal No. 7}

Pasal yang menjelaskan tanda-tanda apabila bertemu dengan Tuhan Pahamilah seluruh yang dijadikan oleh Allah pada tubuh kita dan rasakan segala kenilmatan hakekat dzat-Nya yang tidak ada samanya dan tidak demikian itu kecuali memahaminya dengan baik.

\subsection{Pasal No. 8}

Pasal yang menjelaskan hakekat perkataan yang tujuh itu. Apabila kita mengucapkan "A" itulah kemaha suscian Allah swt, apabila mengucapkan "I" itulah janjinya Allah swt, apabila mengucapkan "U" itulah pancarannya Allah swt apabila mengucapkan "H" itulah kebesaran-Nya, apabila mengucapkan "H" itulah kemaha sempurnaan-Nya apabila mengucapkan "Allahu" demikian itu adalah tempat dzat dan sifat-Nya.

\section{Bagian ketujuh tanpa pasal}

Bagian ini memaparkan hubungan suami istri. Apabila telah dilakukan yang fardhu (penting) dalam hubungan suami isteri. Apabila telah masuk kemaluan (laki-laki) lalu keluarlah air mani, jangan dikeluarkan apabila mati kemaluannmu maka anakanak itu akan pendek umurnya, walaupun hidup dia akan mengalami ketersiksaan (sakit). Karena mati nyawanya. Anak-anak itu adalah nyawanya Allah swt dialah yang mencipatakannya, itulah sehingga sangat baik untuk mencari pada diri kita, jika telah mendapatkan diri kita maka peganglah kemaluan istri kita lalu membaca "Waddu., Waddi, Mani, Maanikum", masuklah dalam batinmu dan inilah tempat masukmu, maka disapulah wajah kita sebanyak tiga kali secara berulang dan diisap pula sikunya sebagnyak tiga kali inilah yang dinamakan tempat pengembalian

\section{Bagian kedelapan dengan satu pasal}

Adapun shalat shubuh itu dia yang menyembah dirinya, adapun dhuhur Dia yang melakukannya, adapun ashar itu Dia yang Satu (Esa), adapun magrib Dia yang memiliki, adapun isya Dia yang Maha Besar, adapun witir yang dua rakaàat itulah yang menciptakan, adapun yang satu raka'at Dialah yang memancar, adapun shalat jum'at itulah yang digembirakan dan itu juga yang disembah.

\subsection{Pasal No. 1}

Pasal ini menjelaskan perumpamaan dan perbandingan shubuh itu diumpamakan dengan roh yang suci tubuh halusnya yang menegakkannya, adapun dhuhuritu diumpamakan Sunnah tubuh kita yang menegakkannya. Adapun perumpamaan ashar diumpakan ushul akal yang menegakkannya, adapun perumpamaan magrib,diumpamakan tahkikah dan misal yang menegakkannya, adapun perumpamaan Isya, para sufilah yang mendirikannya, adapun witir yang dua rakaat diumpamakan Nur Muhammad 
dan nyawa yang mendirikannya adapun witir yang satu raka'at di umpamakan Nur Muhammad, dan rahasia (hakekat) yang mendirikannya adapun perumpamaan jumat diumpamakan Rasulullah saw.

\section{PENUTUP}

Issengngi Majeppu Kode LTMM-IX secara garis besar berisi tentang syariat, tarikat, hakekat, dan makrifat. Selain syariat, tarikat, hakikat dan makrifat, naskah ini juga menyelipkan hubungan suami istri dan ilmu kebal. Karena naskah ini membahas tentang syariat, tarikat, hakikat dan makrifat dalam pandangan sufi, maka dalam naskah ini banyak dikemukan bagaimana cara beribadah,mendekatkan diri kepada Allah dengan dzikir; dalam dzikirnya pun banyak ditemukan bagaimana hakikat hamba dengan khaliknya, selanjutnya dalam melihat hamba dengan khaliknya banyak dilukiskan dalam simbol-simbol huruf alif, ha, mim, dan dal.

Penyajian Issengngi Majeppu Kode LTMM-IX oleh penulisnya ditulis secara mengalir tanpa ada aturan yang mengikatnya. Dengan demikian satu pokok bahasan ditemukan berulan pada bagian yang lain.

Ada beberapa hal yang kelihatannya bertentangan dengan syariat (fiqhi) yang ada pada umumnya. Seperti perlakuan suami istri saat saat berhubungan, yang oleh masyarakat awam dijadikan legitimasi bahwa tak perlu mandi junub setelah berhubungan. Dari itu diperlukan peneliti di bidang tasawwuf bersama ahli fiqhi untuk mengkajinya lebih dalam.

\section{UCAPAN TERIMA KASIH}

Terima kasih penulis ucapkan kepada semua pihak yang telah memberikan saran dan masukan terhadap tulisan ini, rekan-rekan peneliti dan Kepada Kepala Balai Litbang Agama Makassar serta pengelola Jurnal Al-Qalam atas termuatnya tulisan ini. Dan semoga Naskah Issengngi Majeppu dapat menambah wawasan bagi pembacanya.

\section{DAFTAR PUSTAKA}

Departemen Pendidikan dan Kebudayaan. 2002. Kamus Besar Bahasa Indonesia. Edisi Ketiga. Jakarta: Balai Bahasa.

Djamaris, Edwar. 1977. Filologi dan Cara Kerja Filologi. Jakarta: Pusat Pembinaan dan Pengembangan Bahasa.
1991. Tambo Minangkabau: Suntingan Teks Disertai Analitis Struktur. Jakarta: Balai Bahasa.

1993. Metode Penelitian Filologi. Jakarta: Pusat Pembinaan dan Pengembangan Bahasa.

Hinta, Elliyana G. 2005. Tinilo Pa'ita, Naskah Puisi Gorontalo: Sebuah Kajian Filologis. Jakarta: Djambatan.

Idham. 2011. Pulau Tidore: Segudang Naskah Menunggu Belaian Filolog, dalam Jurnal Manassa, Vol. 1, No. 1, Juni 2011.

Ikhwan, Munirul. 2009. Kitab al Munir of Jalal al-Din al Suyuti: A Critical Edition and Translation of Section Twenty on Islamic Terms, dalam Al Jamiah Journal Of Islamic Studies UIN Sunan Kalijaga Yogyakarta, Vol. 47, No. 2, $2009 \mathrm{M} / 1430 \mathrm{H}$.

Ikram, Achadiati. 1987. Kegiatan Filologi di Indonesia. Makalah dibacakan pada Penataran Filologi Tahap I Kerjasama LERES IAIN Sunan Kalijaga - Fakultas Sastra UGM.

Ilyas, Husnul Fahimah. 2011. Lontaraq Suqkunas Wajo: Telaah Ulang Awal Islamisasi di Wajo. Jakarta: Sekolah Pascasarjana Universitas Islam Negeri (UIN) Syarif Hidayatullah.

Mulyadi, S.W.R. (ed). 1994. Kodikologi Melayu di Indonesia. Lembaran Sastra Universitas Indonesia. Depok: Fakultas Sastra Universitas Indonesia.

Paeni, Mukhlis, dkk. 2003. Katalog Induk NaskahNaskah Nusantara Sulawesi Selatan. Jakarta: Arsip Nasional Republik Indonesia Ford Foundation, Universitas Hasanuddin, Gadjah Mada University Press.

Pradotokusumo, Partini Sardjono. 1984. Suntingan Naskah serta Karya Sastra Kakawin Abad ke20: Suntingan Naskah serta Struktur, Tokoh dan Hubungan Antarteks. Bandung: Bina Cipta.

Pradotokusumo. 1998. Penerjemahan Bahasa Jawa (Kuna - Tengahan Baru). Makalah Temu Ilmiah ke-3 Ilmu-Ilmu Sastra Program Pascasarjana Unpad Bandung.

Soemantri, Emuch Herman. 1986. Identifikasi Naskah. Bandung: Fakultas Sastra Universitas Padjajaran.

Soeratno, Siti Chamamah. 1996. Naskah Lama dan Relevansinya Dengan Masa Kini. Makalah: Simposium Tradisi Tulis Indonesia.

Yusuf, Choirul Fuad. 2012. Lektur dan Khazanah 
Keagamaan: prospek Pengembangan, dalam Jurnal Lektur Keagamaan Puslitbang Lektur dan Khazanah Keagamaan Badan Litbang dan Diklat Kementerian Agama Ri, Vol. 10, No. 1, Juni 2012. 